\section{International Scientific Journal Theoretical \& Applied Science}

\author{
p-ISSN: 2308-4944 (print) e-ISSN: 2409-0085 (online) \\ Year: $2018 \quad$ Issue: $06 \quad$ Volume: 62
}

Makhamedkali Kenzhekhojayev Candidate of Technical Sciences, Associate professor Head of the department «Technology of food products, processing industries and biotechnology»

M.Kh. Dulaty Taraz State University, Kazakhstan

SECTION 23. Agriculture. Agronomy. The technique.

\title{
INVESTIGATION OF THE INFLUENCE OF LACTULOSE ON THE PROPERTIES OF A FERMENTED MILK DRINK DURING STORAGE
}

Abstract: Squashing is carried out using starter microorganisms, which must be kept alive and present in the finished product in a predetermined amount.

The whole process of production of fermented milk products, as well as the quality of the finished product, depends on the quality of the ferment. From the used starter cultures, the taste of the product and its texture depend. Today, a huge number of starter cultures, consisting of one kind of microorganisms or from their combinations, allows you to create a product with almost any specified characteristics.

Key words: strain, bacterial leaven, lactobacillus bacteria, probiotics, prebiotics, lactobacilli.

Language: English

Citation: Kenzhekhojayev M (2018) INVESTIGATION OF THE INFLUENCE OF LACTULOSE ON THE PROPERTIES OF A FERMENTED MILK DRINK DURING STORAGE. ISJ Theoretical \& Applied Science, 06 (62): 16-19.

Soi: http://s-o-i.org/1.1/TAS-06-62-3 Doi: crossef https://dx.doi.org/10.15863/TAS.2018.06.62.3

\section{Introduction}

Milk and dairy products are very widely used in nutrition of various layers of the population, remaining the main product for the majority of consumers all over the world. In countries that have significant economic, geographical and social differences, milk is considered an integral part of healthy nutrition for people of all ages. Even despite the economic crisis, milk consumption continues to grow $[1,2]$.

Everyone knows that sour-milk products are useful for both adults and children. Modern research confirms that regular use of sour-milk products strengthens health and prolongs life. All fermented milk products improve appetite, have a relaxing effect, and also remove radionuclides, heavy metal salts, toxins and slags. The vital activity of our body in modern conditions is adversely affected: environmental ill-being; stressful effects; mass use of antibiotics and chemotherapeutic drugs; unbalanced nutrition. All these risk factors destroy the intestinal microflora. By the term "Functional nutrition" means the use of so-called "functional food products" special foods intended for systematic use, with scientifically validated and confirmed properties, which reduce the risk of developing food-related diseases that prevent a deficit or replenish existing in the human body deficiency of nutrients, preserving health due to the presence in its composition of natural functional ingredients $[3,4,5]$.

The benefits of fermented milk products can be judged by comparing them with milk. For an hour, milk is absorbed by the human body only by $32 \%$, while yogurt, curdled milk and other sour-milk drinks - almost completely. Milk is more likely to cause allergies. In addition, as you grow older, some people begin to experience symptoms of lactose intolerance to lactose. And lactic acid bacteria produce substances that promote the assimilation of milk sugar and heavily digestible proteins.

Fermented milk products are obtained by fermenting milk or cream with pure cultures of lactic acid bacteria, sometimes with the participation of yeast and acetic acid bacteria. In the process of fermentation, complex microbiological and physicochemical processes take place, as a result of which the taste, smell, consistency and appearance of the finished product are formed.

Squashing is carried out using starter microorganisms, which must be kept alive and present in the finished product in a predetermined amount.

The main factors affecting the structural and mechanical properties of fermented milk products are the appearance and activity of bacterial leaven. 


\begin{tabular}{|c|c|c|c|c|c|c|}
\hline Impact Factor: & $\begin{array}{l}\text { ISRA (India) } \\
\text { ISI (Dubai, UAE } \\
\text { GIF (Australia) } \\
\text { JIF }\end{array}$ & $\begin{array}{l}=1.344 \\
=0.829 \\
=0.564 \\
=1.500\end{array}$ & $\begin{array}{l}\text { SIS (USA) } \\
\text { PИНЦ (Russia) } \\
\text { ESJI (KZ) } \\
\text { SJIF (Morocco) }\end{array}$ & $\begin{array}{l}=0.912 \\
=0.207 \\
=4.102 \\
=\mathbf{2 . 0 3 1}\end{array}$ & $\begin{array}{l}\text { ICV (Poland } \\
\text { PIF (India) } \\
\text { IBI (India) }\end{array}$ & $\begin{array}{l}=6.630 \\
=1.940 \\
=4.260\end{array}$ \\
\hline
\end{tabular}

An important biochemical process in the production of fermented milk products is the fermentation of milk sugar, caused by microorganisms of bacterial ferments.

According to the nature of lactic acid fermentation, sour-milk drinks can be divided into two groups: to the first group - products based on lactic fermentation (yogurt, acidophilus); to the second group - products of mixed fermentation, during the preparation of which both lactic and alcoholic fermentation takes place (kefir, kumis, acidophilic yeast milk, etc.) $[6,7,8]$.

During 18-22 hours, when the product is fermented with lactic acid bacteria, favorable changes occur in the milk: lactose is broken, so that most people tolerate dairy products, unlike whole milk, the intolerance of which is associated with the absence of a special enzyme in the intestine that disengages milk sugar; partially break down proteins, acquiring a finely dispersed structure, which improves their absorption by the body (whole milk is digested in an hour by $32 \%$, and kefir by $91 \%$ ); accumulates lactic acid, which prevents the development of putrefactive microorganisms and promotes the growth of normal intestinal microflora; increases the amount of $\mathrm{B}$ vitamins; natural antibiotics are developed that can depress the causative agents of many diseases; accumulate useful bacteria that protect the intestinal mucosa from the introduction of pathogenic microbes into it $[9,10$,$] .$

Thus, by combining different types of fermenting bacteria and controlling the temperature during ripening, a product with the desired consistency, flavor, aromatic and dietary properties can be obtained $[11,12]$.

The main goal of this stage of the work was to study the effect of lactulose on the properties of a fermented milk drink.

The results of measurements of the $\mathrm{pH}$ value during the storage of samples of fermented milk ice cream for 2 months at a temperature of $-4^{\circ} \mathrm{C}$ are presented in table 1 .

Table 1

Change in active acidity of samples of fermented milk during storage

\begin{tabular}{|c|c|c|c|}
\hline \multirow{2}{*}{ Sample } & \multirow{2}{*}{ Number of Experience } & \multicolumn{2}{|c|}{ The value of active acidity (pH) } \\
\cline { 2 - 4 } & & A month later & Two months later \\
\hline Without & 1 & 4.40 & 4,43 \\
making & 2 & 4.41 & 4,46 \\
lactulose & 3 & 4.37 & 4,44 \\
\cline { 2 - 4 } & Average & $4,39 \pm 0,02$ & $4,44 \pm 0,01$ \\
\hline From & value & & 4,50 \\
making & 1 & 4,52 & 4,49 \\
lactulose & 3 & 4,49 & 4,50 \\
\hline & Average & $4,49 \pm 0,02$ & $4,49 \pm 0,05$ \\
\hline
\end{tabular}

The data presented in the table make it possible to conclude that the application of lactulose does not affect the post-acidification of the samples of the sour-milk drink during storage.

Survival of microflora of starter cultures under storage conditions

The most important in the development of technology of fermented milk products is the survival of the microflora of starter cultures under storage conditions.

One of the priority tasks in the production of a fermented milk product is to ensure a high survival rate of the microorganisms of the starter microflora. The next stage of the study was the determination of the effect of lactulose on the preservation of the viability of the fermented microflora under conditions of storage of samples of a fermented milk beverage at minus $4^{\circ} \mathrm{C}$ for 20 days.

The results of determining the amount of mesophilic lactococci in the mixture after fermentation during storage after freezing are shown in Figure 1.

Based on the data obtained, it can be concluded that the application of lactulose has a positive effect on the preservation viability of the microflora of bacterial leaven during the storage of samples of a sour-milk drink, after 20 days of storage, the amount of live lactic acid microorganisms in the prototypes was higher by $26.8 \%$ 


\begin{tabular}{|c|c|c|c|c|c|c|}
\hline Impact Factor: & $\begin{array}{l}\text { ISRA (India) } \\
\text { ISI (Dubai, UAE } \\
\text { GIF (Australia) } \\
\text { JIF }\end{array}$ & $\begin{array}{r}=1.344 \\
=0.829 \\
=0.564 \\
=1.500\end{array}$ & $\begin{array}{l}\text { SIS (USA) } \\
\text { PИНЦ (Russia) } \\
\text { ESJI (KZ) } \\
\text { SJIF (Morocco) }\end{array}$ & $\begin{array}{l}=0.912 \\
=0.207 \\
=4.102 \\
=2.031\end{array}$ & $\begin{array}{l}\text { ICV (Poland) } \\
\text { PIF (India) } \\
\text { IBI (India) }\end{array}$ & $\begin{array}{l}=6.630 \\
=1.940 \\
=4.260\end{array}$ \\
\hline
\end{tabular}

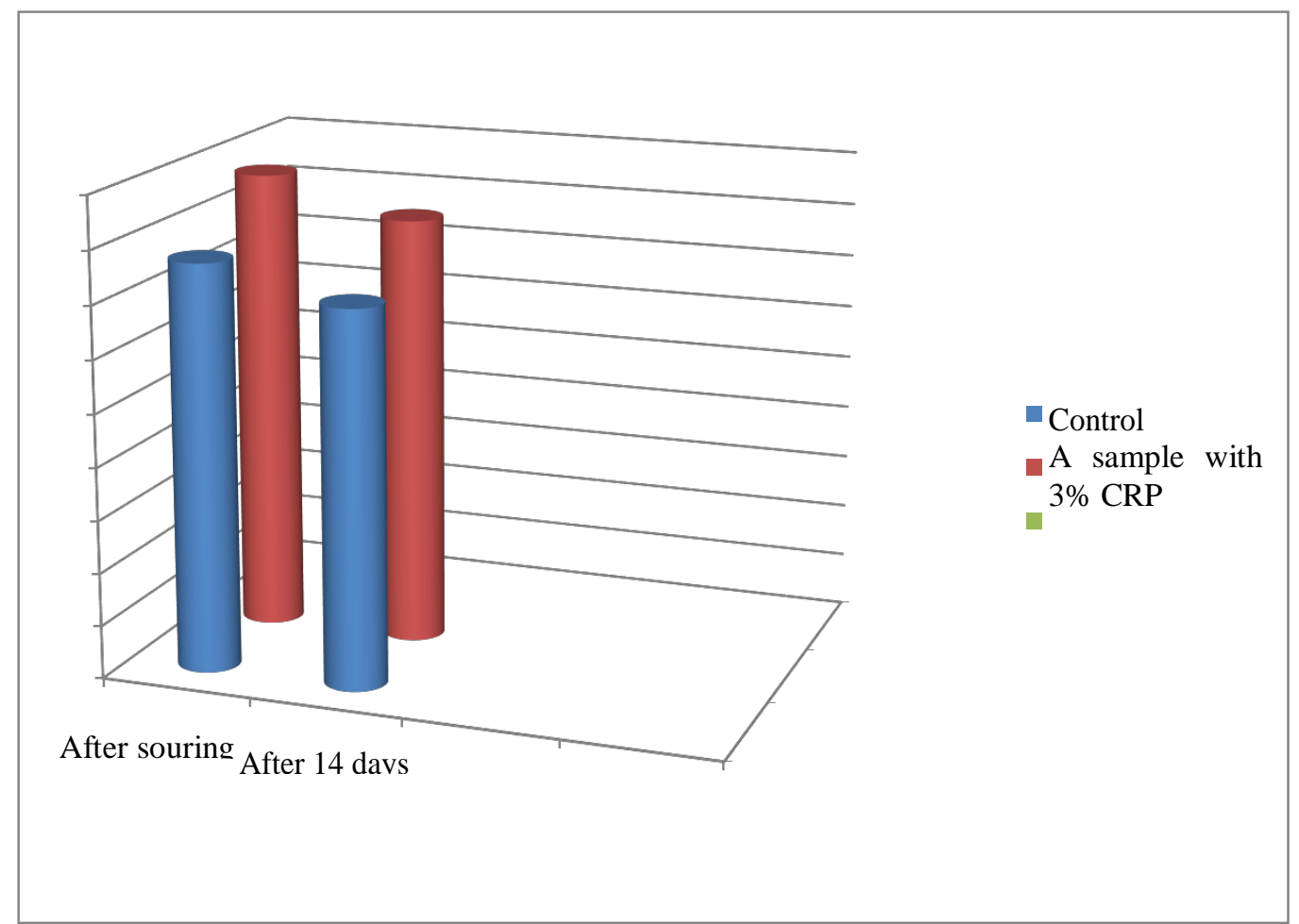

Figure 1 - Effect of lactulose on the ferment microflora in mixtures for fermented milk ice and finished product during storage (control - without lactulose, experience - 3\% lactulose)

At the next stage of the work, the effect of GOS on the development of mesophilic lactococci during the ripening process and survival during storage of the mixture at a temperature of $(2 \pm 4){ }^{\circ} \mathrm{C}$ for 2 weeks were investigated. The results of the studies are shown in Figure 2.

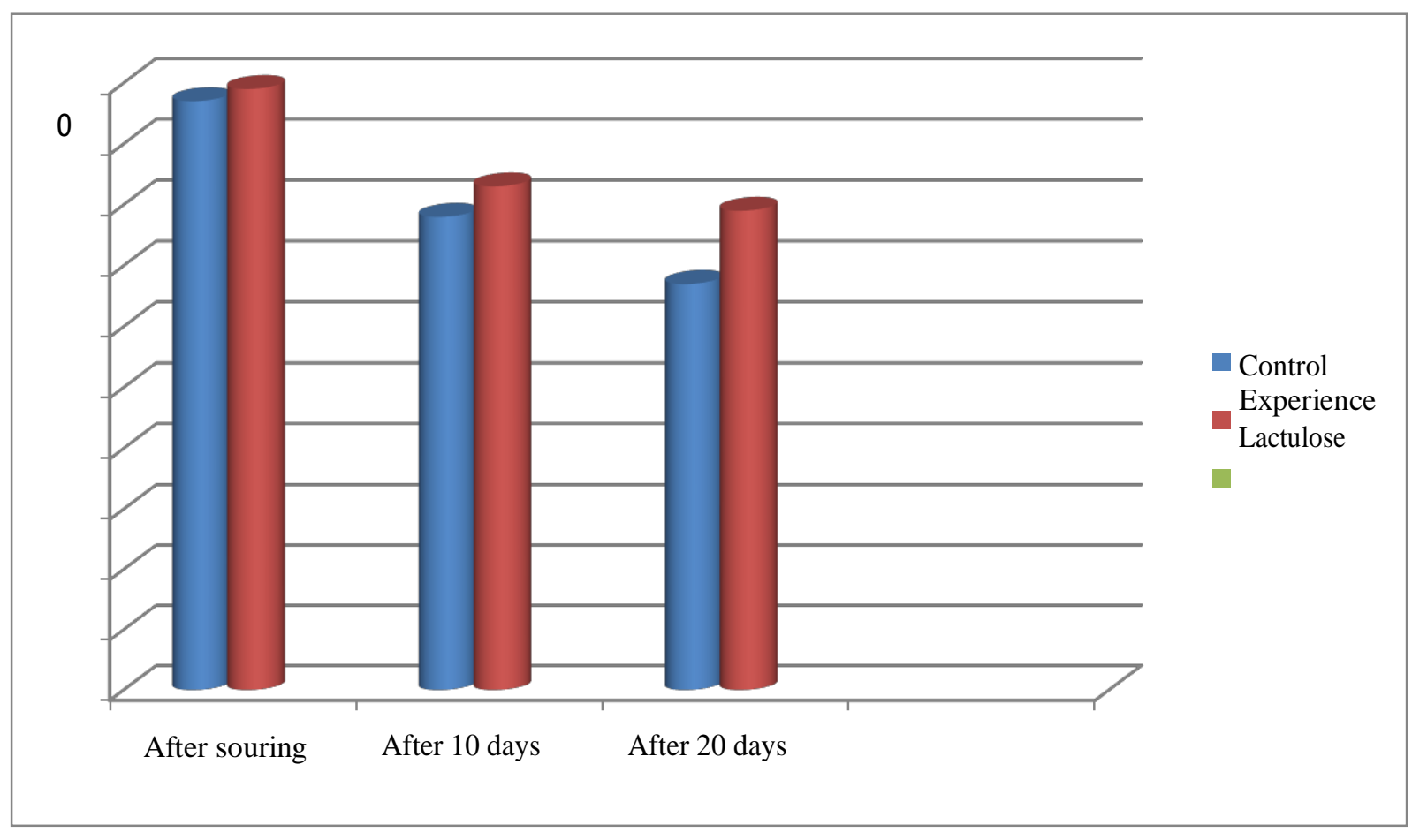

Figure 2 - Effect of GOS on the number of mesophilic lactococci. 
The analysis of the diagrams in Fig. 3.7 shows that the number lactic acid microorganisms in pilot samples after ripening is higher than in control - with GOS-1 by $13.9 \%$, with GOS-2 - by $15.2 \%$. The introduction of GOS drugs also significantly influenced the survival of lactococci during the storage of mixtures $-14 \%=18 \%$ more viable cells of the starter microflora survived in the test samples than in the samples without galactooligosaccharides. Based on the data obtained, it can be concluded that the application of galactooligosaccharides has a positive effect on the development and preservation of the viability of the microflora of the bacterial leaven LAT CW.

\section{Conclusion}

An important biochemical process in the production of fermented milk products is the fermentation of milk sugar, caused by microorganisms of bacterial ferments.

Thus, the study of the issue of obtaining a variety of starter cultures for the production of lactic acid products, both on the basis of lactobacilli and bifidobacteria, is extremely topical in the sphere of providing the population with high-quality, functional and inexpensive food products.

The addition of $3 \%$ lactulose syrup has a positive effect on the preservation of the viability of the microflora of the bacterial ferment during the storage of ice cream.

The use of galacto-oligosaccharides positively affects the characteristics of the fermented milk product, its taste, improves the survival of microorganisms of bacterial culture LAT CW L under low-temperature storage.

\section{References:}

1. Zakharova, N.G. (2012) Microbiology in definitions and illustrations [Text] / N. G. Zakharova, V.I. Vershinina, ON Ilinskaya. Kazan: Publishing house "Feng", 2012. - p. 799.

2. Irkitova, A.N. (2011) Comparative evaluation of strains of acidophilus rod for use in probiotic products [Text] / A.N. Irkitova // Bulletin of the Ural Medical Medical Science - 2011.- p. 30 32.

3. Pimenova, M.N. (1995) A Guide to Practical Studies in Microbiology [Text] / M. N. Pimenova, N.N. Grechushkina, L.G. Azov. M.: Publishing House of Moscow State University, 1995. - p. 224.

4. Irkitova, A.N. (2012) Comparative analysis of methods for determining the antagonistic activity of lactic acid bacteria [Text]/ A.N. Irkitova, Ya.R. Kagan, G.G. Sokolov // News of the ASU. - 2012. - T.3. - p. 41-44.

5. Tochilina, A.G. (2009) Biochemical and molecular-genetic identification of bacteria of the genus Lactobacillus [Text]: author's abstract. dis. ... Cand.Biol. Sciences / AG Tochilina; NGMA. - N.Novgorod. - 2009. - p. 26.

6. Karapetyan, K.J. (2008) Effect of the composition of the nutrient medium on the manifestation of the antimicrobial properties of some lactic acid bacteria. [Text] / KJ Karapetyan, A. S. Akopyan, F.N. Тхруни, Ц.P. Balabekyan // Scientific notes of the Yerevan State University. - 2008.-T.3 - p. 125-130.
7. Mudretsova-Wiss, K.A. (2009) Microbiology, Sanitation and Hygiene [Text] K.A. Mudretsova-Viss, V.P. Dedyukhin; ID "FORUM" - Moscow: INFRA-M, 2009. - p. 400.

8. Chicherin, I.Yu. (2013) Dynamics of the content of lactobacilli, microbial metabolites and antibacterial activity of the growing culture of Lactobacillus Plantarum 8P-A3 [Text] / I.Yu. Chicherin1, I.P. Pogorelsky, I.A. Lundovskikh, A.A. Malov, M.R. Shabalin // Journal of Infectology. - 2013.- T.3. - p. 50-55.

9. Piksasova, O.V. (2009) A new approach to molecular diagnostics of bifidobacteria [Text]: avtoref. dis.cand. Biol. Sciences / O.V. Piksasova MSU. - M., 2009. - p. 25.

10. Rogov, I.A. (2006) Synbiotics in food technology: monograph [Text] / I.A. Rogov, E.I. Titov, V.I. Ganina. - Moscow: MGUPB, 2006. - p. 218.

11. (1983) Methods of general bacteriology [Text] / / M .: Mir.- 1983. - T.1. - p. 534.

12. Khabibullin, R.E. (2013) Comparative characteristics of nutrients mediums for rehydration and reactivation of lyophilized bacteriological starter cultures [Text] / RE Khabibullin, SA Zhakslykova, ARNizamieva, G.Ya. Yakovleva, OA Reshetnik // Bulletin of Kazan Technological University .- 2013.- T.16, No. 11, p. 217-219. 